\title{
SIMULATION MODELS IN TESTING RELIABILITY OF TRANSPORT PROCESS
}

\section{MODELE SYMULACYJNE W ZASTOSOWANIU DO BADANIA NIEZAWODNOŚCI PROCESÓW TRANSPORTOWYCH}

\author{
Marianna Jacyna, Jolanta Żak \\ Warsaw University of Technology \\ maja@wt.pw.edu.pl; j.zak@wt.pw.edu.pl
}

\begin{abstract}
The paper touches the problem of applying simulation models to assess the reliability of services in transport networks. Investigation of the transport processes in terms of their reliability is a complex decision-making task. The paper describes a method for assessing the reliability of transport process on the base of the criterion of minimizing the normalized lost time of vehicles. The time is wasted in a result of conflict situations occurring in the transport network during the transport process. The study includes stochastic distributions of system input. It enables studying the quality parameters of the transport network equipment, including service providers working under different workload and all kinds of disturbances. The method uses simulation models. Simulation studies were performed with Java Modelling Tools.
\end{abstract}

Keywords: reliability of transport processes, simulation models, transport processes

Streszczenie: Tematem publikacji jest wykorzystanie modeli symulacyjnych do oceny niezawodności realizacji ustug $w$ sieciach transportowych. Badanie przebiegu realizacji procesu transportowego $w$ aspekcie niezawodności realizacji ustug jest złożonym procesem decyzyjnym. $W$ artykule zaproponowano metode ocene niezawodności realizacji procesów transportowych $w$ oparciu o kryterium minimalizacji ważonych strat czasu jednostek transportowych, które powstaty na skutek sytuacji konfliktowych wystepujacych w sieci transportowej podczas przebiegu procesu transportowego. $W$ badaniach uwzględniono stochastyczne rozklady strumienia zgloszeń, co umożliwia badanie jakości parametrów wyposażenia sieci transportowej, $w$ tym operatorów ushug, przy różnym obcią̇eniu oraz przy wszelkiego rodzaju zakłóceniach. Metoda uwzględnia zastosowanie modeli symulacyjnych. Badania symulacyjne przeprowadzono $z$ wykorzystaniem aplikacji Java Modelling Tools.

Stowa kluczowe: niezawodność procesów transportowych, modele symulacyjne, proces transportowy 
Simulation models in testing reliability of transport process

Modele symulacyjne w zastosowaniu do badania niezawodności procesów...

\section{SIMULATION MODELS IN TESTING RELIABILITY} OF TRANSPORT PROCESS

\section{Introduction}

Issues concerning transport are the research subject of many scientists. This is a result of current striving, especially by governments and official bodies, for using those forms of freight and passenger transport which provide:

- reducing congestion,

- energy savings,

- less negative impact on the environment,

- high efficiency.

The primary objective of the research on transport systems is the relationship between performed tasks, equipment and organization. Each system - also transport system, changes during its life-time. Therefore, it should contain features permitting the mapping of the waveform of these changes. Research on transporting passengers and freight requires mapping [4]: transport network, rolling stock, all types of service stations for passengers and freight traffic, security devices as well as employees.

The various stages of transport process require making decisions about controlling the process execution [1]. Decisions affect the course of the process and fulfil the boundary conditions resulting from network and equipment restrictions and customer expectations. Since the transport process involves various stakeholders, it is essential to apply organization ensuring the process reliability under the tasks declared by the purchasers of transport services [1].

Considering the above, the transport process evaluation criteria must include the reliability of the process and effectiveness of transport tasks realization.

The assessment of transport processes bases on process progress analysis and can be made through simulation tests performed on the models of the systems [1]. Simulation tests allow observing the effects of used equipment and organization on the systems performance and make a preliminary assessment of the reliability associated with its functioning.

\section{Areas of implementation of the transport processes}

It was assumed that the transport process is a series of successive changes of states of transport system occurring between the initial state and the final state. The state of the transport system in particular moment of time is defined as a state of road elements (the road and rail network, line and nodal elements including systems securing traffic, etc.) and the status of vehicles or whole traffic stream. Thus, the states of individual elements of roads and conditions of individual vehicles are components of the state of transport system.

The transport system includes elements involved in and elements realizing moving persons or goods and items related to the process of movement [15], [4]. Transport processes are characterized by the relationship between the states of road sections and vehicle conditions. The states of road segments designate unambiguously states of vehicles, and vice versa. 
Carrying out the unit of traffic through the system is associated with the transformation of input units into output units. Transformations of input streams into output streams is shown in Figure 1.

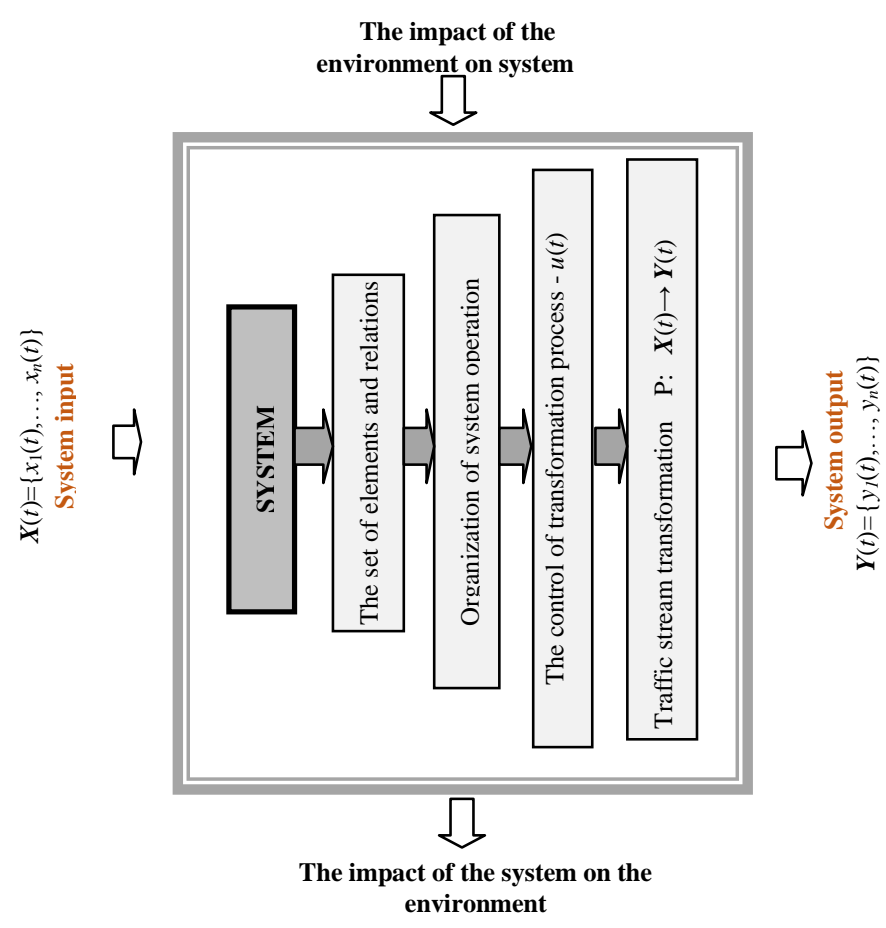

Fig. 1. Transformation of input traffic stream into output stream. Source: [15].

Mapping the transport process in the model requires a number of assumptions to be determined: transport relation, type, number and characteristics of objects moved in the transport system. At the same time the variable intensity of traffic flow makes transport processes being either stationary or, more often, nonstationary which makes it difficult to research.

The analysis of literature revealed that the problem of transport processes covers the following areas:

1. Moving the traffic stream through the elements of transport infrastructure including mapping:

- the speed and road capacity as a function of traffic,

- the formation and size of queues in the infrastructure components,

- traffic congestion, including congestion control.

2. Traffic lights control.

3. Servicing passengers and cargo including:

- optimization of departure times and volumes of freight, 
Simulation models in testing reliability of transport process

Modele symulacyjne w zastosowaniu do badania niezawodności procesów...

- estimation of inventory as a function of production and distribution continuity,

- scheduling the vehicles movement on routes with many stopping points, time separation between courses and its impact on customer decisions, including composing and testing schedules,

- planning of production and distribution like making decisions on types of vehicles, service frequency, etc.

4. Processes characteristic for air transport and operation of airports including:

- queuing take-off and landing,

- Take-off and landing operations [3],

- The luggage handling process in airports.

5. Processes in railway transport including:

- performance analysis of nodal stations as a function of empty wagons flow, trains operations and maintenance capabilities,

- shunting in marshalling yards,

- the order of trains (passing sidings, stations etc.) on the line,

- traffic control taking into account speed, priorities, technical condition of infrastructure and timetables.

6. Warehousing processes including:

- determining the storage capacity of the functional areas or buffers,

- analysis of transport systems at the entrance and exit of the warehouses,

- queuing receptions and receiving of materials.

Researches in all listed issues require building the models for analysis the course of the phenomena occurring in the transport system. The paper touches the analyses of transport process in the area of rail transport.

\section{The net of phases method applied for testing the reliability of the transport process}

According to the definition, the reliability is the ability of the object to meet posed requirements. It can be measured be a probability of meeting the requirements. The reliability assessment must take into account the operation time of the object (system) in which the analyzed object (system) has a normal running order (is efficient). The measure in this case can base on time, the amount of work done, the number of steps taken, distance traveled, etc.

In technical terms, in accordance with PN-93 / N-50191 [13] the reliability of the system (technical object) is defined as a set of properties that describe the readiness of the object and affecting its: durability, maintainability and supportability. Another definition distinguishes two types of reliability: probabilistic and deterministic, depending on taking into account (or not) random characteristics of the data (of the system). 
In case of probabilistic models reliability of the object $\boldsymbol{R}$, it is given by:

$$
R(t)=P(T \geq t)
$$

where: $R(t)$ - the reliability of the object $R$ in time moment $t$

$P(T \geq t)$ - the plausibility that the object will be operational (durability), longer than the $t$. Persistence $T$ may be expressed by time or length in $\mathrm{km}$.

Many scientists were concerned with reliability in the area of logistics. I. JacynaGolda in [6] was researching the reliability of supply chains. The reliability of logistics systems is discussed by T. Nowakowski [12] and L. Bukowski [2].

The evaluation of transport process reliability is mostly based on time measure. In some cases both early arriving and delay in arrival are the failure in transport. A measure of transport process reliability is then formulated as:

$$
R(t)=P\left(t-t_{w} \leq T \leq t+t_{s}\right)
$$

where: $t-t_{w}-$ the earliest allowable arrival time.

$t+t_{s}-$ latest allowable time of arrival.

The realization of every task by the transport system can be divided into several stages. Modelling of such systems and assessment of their reliability with classical techniques of reliability theory does not bring the expected results always. In this case other calculation methods like modelling by Markov processes or reliability phasic diagrams (structures) [9] are proposed. One of the methods basing on Markov processes is the net of phases method presented in [15].

Transport processes are characterized by relations between the states of the roads segments and states of vehicles. The states of road segments designate unambiguously states of vehicles, and vice versa. This relationship significantly reduces the number of possible states of the transport system. The state vector of the transport system can be presented as a sequence of changes in infrastructure or as a sequence of changes of vehicles (railway or road) states. The net of phases states that the state of the system is a phase of the process and the change of state (transition from one to the next phase of the process) is defined as an event.

The resulting structure is a net of movement process phases. It was assumed that the phase of the process is characterized in time domain by its duration, and the event is characterized by time of its occurrence. In this arrangement the structure of net of movement process phases maps the transport structure and reproduces process of traffic units movement in the transport network.

Exemplary transition from the transport network structure to the net of process phases in shown in Figure 2. 


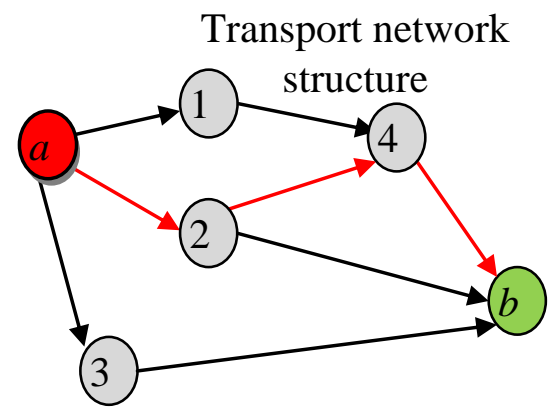

Route $\langle a, 2,4, b\rangle$ in structure $\mathrm{G}=\langle\mathrm{W}, \mathrm{L}\rangle$

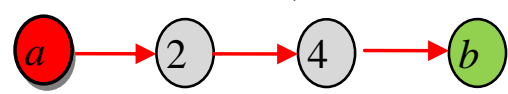

Structure of net of process phases for route $\langle a, 2,4, b\rangle$

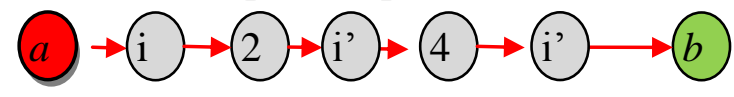

Fig. 2. The exemplary transition of transport network structure into net of process phases Source:[15].

Each phase is presented as a simple queuing system (SMO). This means that for each phase exists an input stream of traffic units (vehicles) following to the next phase of operation, the waiting room as for vehicles waiting for service, the service station and the stream of serviced vehicles.

Under these assumptions, the net of process phases maps the relationship between the phases of the process while the structure of the net maps the structure of transportation process where each phase is a node and event is edge.

Thus, the node of net (depending on the situation) may map both the point components of road (nodes) and line components (transport links).

Considering the above, model of transport processes (MPTSF) will be descripted as ordered four:

$$
\mathrm{MPTSF}=<\text { GFSP, FFSP, ZST, SFP }>
$$

where:

GFSP - structure of net of process phases,

FFSP - set of functions defined on elements of the net of process phases structure.

ZST - input stream volume.

SFP - control set by traffic organization.

Each phase has a clearly defined duration. Therefore, the system reliability structure varies depending on the current tasks. To achieve the objective - reach the end point each task must be performed and eventual loss of time measuring reliability can't exceed limits. When the time of the vehicle stay in the system is higher than expected, it is assumed that the main objective was unsuccessful. 


\section{Simulation models of transport processes}

As it was mentioned in introduction to consider transport process the appropriate model is necessary to enable simulation studies. To build the model one must map all characteristics of the process relevant for research. Studying the process with the constructed model aims in looking answers to questions about the transport services reliability level.

Simulation models enable imitation of process performed by system what results in information that can be applied in reality. Therefore, a model is useful when one needs to determine the effects of different decisions during design or analysis of existing solutions. The literature provides many examples of the use of simulation techniques to describe the transport problems. For example, J. Leszczynski presented a formalized description of event-triggered simulation model marshalling yard. Ambroziak T. and M. Jacyna proposed a method for studying the dynamics of transport processes [1] based on queuing theory and dynamic programming. The simulation model of logistics processes based on events time-generator was developed by M. Wasiak [14]. Lewczuk et al. presented a model of warehousing process based on net of process phases [11].

Simulation models allow for experimentation on real transport systems and processes and research on their response on change of their parameters. Thus, special attention should be paid to the stage of identification of model parameters when developing a simulation model for a specific transport system. The correctness of this stage implementation directly affects the correctness of the entire model and conclusions based on it. Verification of assumptions regarding the probability distributions of random variables occurring in the simulation model can be done by Kolmogorov test. In practice it can be noticed that accurate planning of activities carried out in transport systems is desired, but in general - due to the scope of these activities, features like servicing times are different. Hence, probability distributions can be used for their description.

Diagram of the relationship between the real system and simulation model is shown in Fig. 3.

An important part of modelling process is assessing how model corresponds to the actual system and checking if results of the simulation made on model are relevant. In both cases the model evaluation considers the results of the system, not the internal control mechanisms that generate these results.

The qualitative assessment collects and assays instantaneous calculation results of the simulation program. Quantitative reliability assessment of the results of simulation made using the model comes down to a comparison of these results with observations of real system by means of statistical tests of compliance. This involves the use of statistical analysis including analysis of variance (or nonparametric tests of conformity). 
Simulation models in testing reliability of transport process

Modele symulacyjne w zastosowaniu do badania niezawodności procesów...

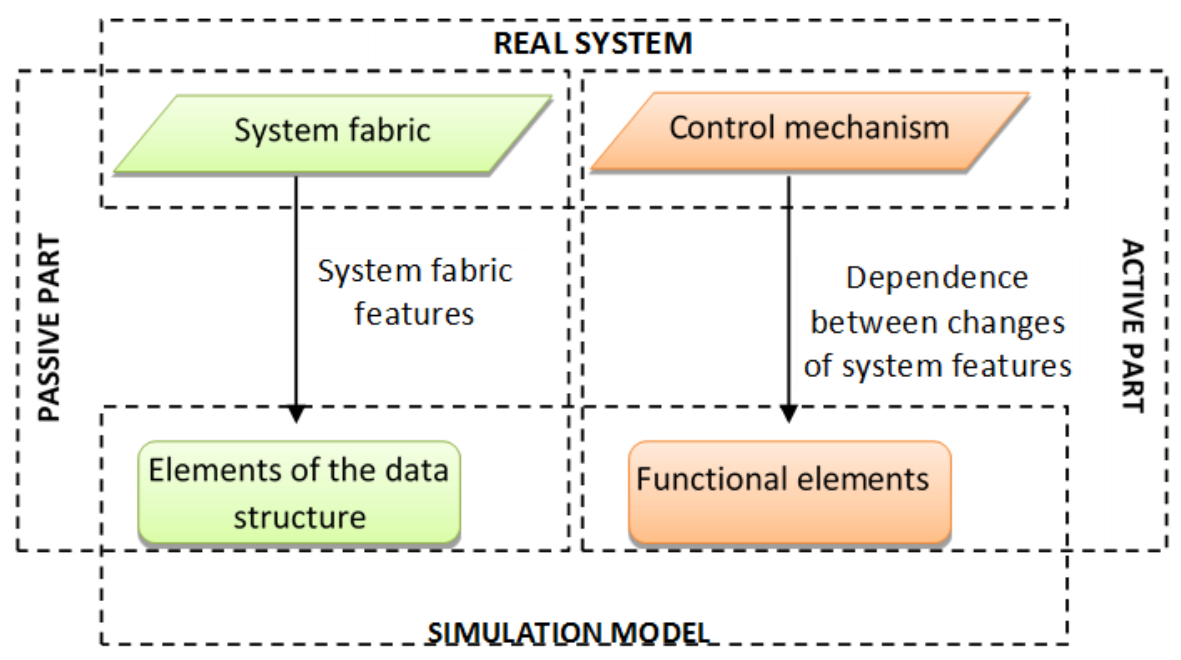

Fig. 3. Dependence between real system and simulation model [15]

\section{Transport process assessment criterion in terms of its reliability}

Considering the transport process reliability the weighted loss of time by vehicles is one of the most important criteria of transport process evaluation. These losses arise from conflicts occurring during transport. Conflict resolution bases on temporary regulating traffic to improve the quality of transportation process in accordance to adopted criterion. It will have sense only when certain freedom of action within the limits imposed by traffic organization and system equipment is given.

The criterion of sum of weighted loss of time by vehicles is calculated by the simulation of consequent decisions about movement of vehicles to the next phase of the process. The most advantageous decision ensuring low losses is applied. Leaving traffic unit in the same phase is allowed when high losses of other entities in the area of analysis are avoided. The area of analyse combines the space defined by number of network nodes with the phases duration, exactly with the waiting time and service duration in nodes of net of process phases. It is convenient to use in such cases the concept of time interval $h$ referred to $v$-node in net of phases and $s t$-vehicle in the area of analysis. To avoid the influence of finite simulation time it is assumed that the analysed time period for each unit of traffic and phase is much shorter than total time of simulation. Loss of time resulting from leaving $s t$-vehicle in $v$-phase of the process in $h$ interval, calculated in relation to time $t_{0}$ when the decision was made is described as $w(v, s t, t)$. The value of time loss function for a single vehicle is $\Delta T(v, s t)$ and given as follows:

$$
\forall v \in \boldsymbol{V}, \quad \forall s t \in \boldsymbol{S} \boldsymbol{T} \quad \Delta T(v, s t)=\int_{t_{0}}^{t_{0}+h} \omega(v, s t, t) d t
$$


The value of time loss function in the reporting period for all vehicles was marked as $\Delta T(v)$ and expressed as follows:

$$
\forall v \in \boldsymbol{V} \quad \Delta T(v)=\sum_{s t \in S T} \int_{t_{0}}^{t_{0}+h} \omega(v, s t, t) d t
$$

The value of the function of total time wasted is marked as $\Delta T$ and given as follows:

$$
\Delta T=\sum_{v \in V} \sum_{s t \in S T} \int_{t_{0}}^{t_{0}+h} \omega(v, s t, t) d t
$$

The assessment of transport process reliability is done by the function of total time wasted A measure of the process reliability is then formulated as:

$$
R(t)=P\left(\Delta T \leq t_{g}\right)=P\left(\sum_{v \in V} \sum_{s t \in S T} \int_{t_{0}}^{t_{0}+h} \omega(v, s t, t) d t \leq t_{g}\right)
$$

where: $t_{g}$ - maximal wastes.

\section{The reliability of trains movement on railway line}

The method of reliability assessment discussed in previous sections was used to assess the movement of train sets on railway lines. The article focuses on reliability of traffic on two routes:

1) West Warsaw - Warsaw Wlochy - section of line 447 West Warsaw - Grodzisk Mazowiecki,

2) Warsaw Wlochy - Pruszkow - section of line 447 West Warsaw West Grodzisk Mazowiecki,

for the basic direction - lanes dedicated for suburban passenger traffic. Diagram of the analyzed sections is shown in Fig. 4.

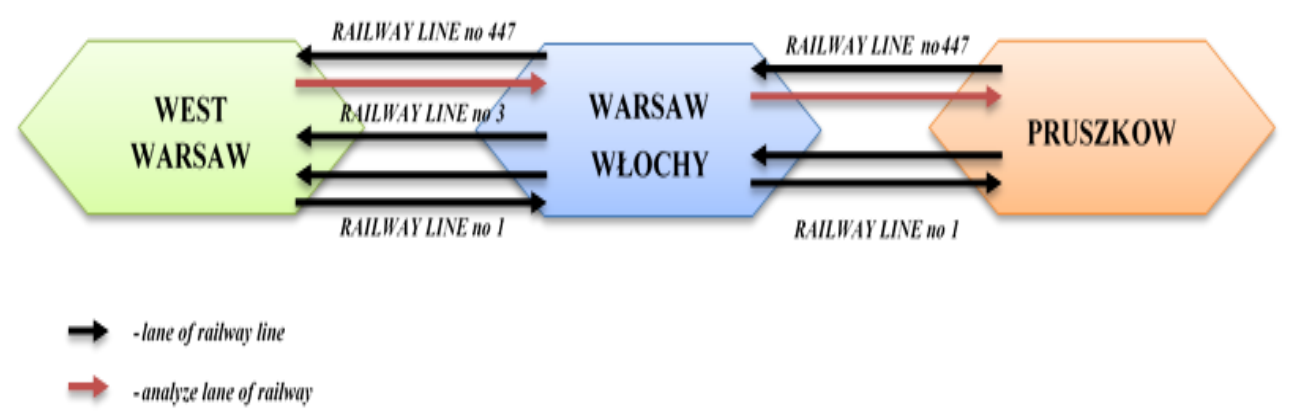

Fig. 4. Diagram of the analysed sections of track 
Simulation models in testing reliability of transport process

Modele symulacyjne w zastosowaniu do badania niezawodności procesów...

The characteristics of analysed routes are shown in Table 1. All analysed routes are equipped with linear railway traffic control devices - a self-locking liner. Accordingly the track is divided into several intervals. Each interval can hold only one train. The devices that affect the reliability of transport process the most (prone to failure) are self-locking liners. Depending on the number of intervals that fail the train must pass them with speed reduced to $20 \mathrm{~km} / \mathrm{h}$ or the phone announcing of train and special command " $\mathrm{S}$ " invalidating the block signals is introduced. The interval can hold only one train again. In both cases passing time increases and time loss rises. When the losses are greater than assumed then process does not satisfy the reliability condition.

The elements of the model are: the source of trains, spacing from automatic block line, individual stations and output of train streams from the system.

The loss of time resulting from different combinations of failures of intervals of automatic line block on the West Warsaw West - Warsaw Wlochy route was analysed. The study assumed that failures of individual block signals are independent and the time loss is not affected by the failure place but their number.

Table 1. Characteristics of analysed sections

\begin{tabular}{|l|c|c|}
\hline Parameter & $\begin{array}{c}\text { West Warsaw - } \\
\text { Warsaw Wlochy }\end{array}$ & $\begin{array}{c}\text { Warsaw Wlochy - } \\
\text { Pruszkow }\end{array}$ \\
\hline Length [km] & 3,722 & $9,087 \mathrm{~km}$ \\
\hline $\begin{array}{l}\text { The average passing time for } \\
\text { the typical train [min] }\end{array}$ & 6 & $11 \mathrm{~min}$ \\
\hline Number of intervals & 5 & 6 \\
\hline Average length of interval [m] & 744 & 1515 \\
\hline $\begin{array}{l}\text { The average passing time of } \\
\text { interval [min] }\end{array}$ & $\begin{array}{c}1,2(3,6 \text { when there is a } \\
\text { failure at the interval of } \\
\text { automatic block line })\end{array}$ & 1,83 \\
\hline $\begin{array}{l}\text { The number of tracks on first } \\
\text { the station }\end{array}$ & 5 & 1 \\
\hline $\begin{array}{l}\text { The number of tracks on last } \\
\text { station }\end{array}$ & 1 & 2 \\
\hline
\end{tabular}

Simulation tests of the reliability of the process of trains movement on the analysed railway was performed with Java Modelling Tools - JSIMgraph in five stages. First stage was carried out for option 0 (existing situation), then for options 1-3, corresponding to the situation that will take place after the appropriate number of automatic block line failures on the route West Warsaw - Warsaw Wlochy, and option 4 corresponding to the case of telephone announcing of trains on this route. Figures 5 and 6 show the model of railway for options $0-3$ and option 4 in Java Modelling Tools application. 


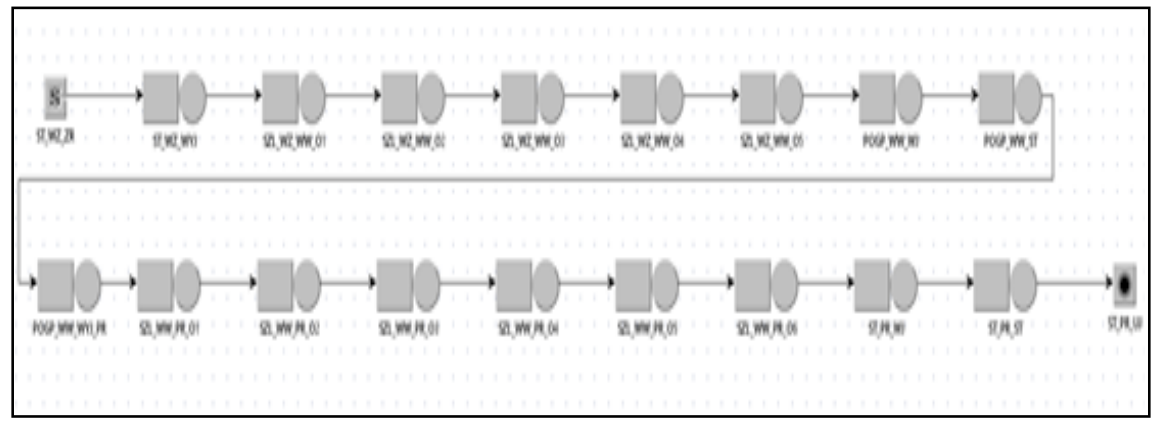

Fig. 5. Model of railway line depicted as a net of process phases for options 0-3 in Java Modelling Tools application.

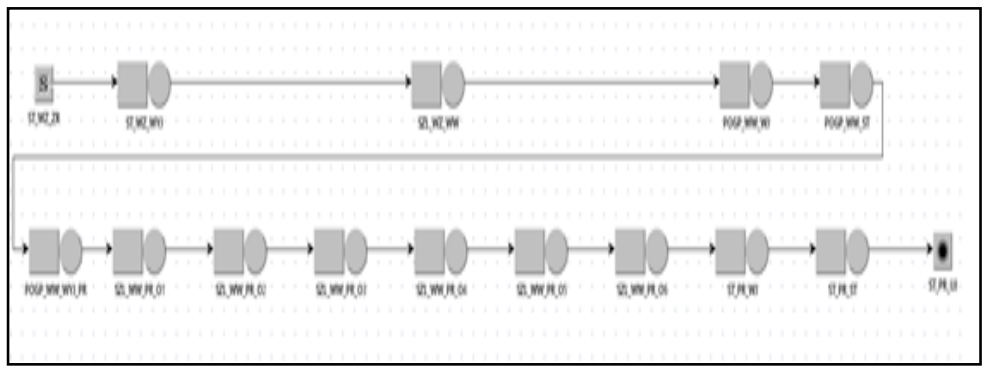

Fig. 6. Model of railway line for option 4 in Java Modelling Tools application.

The model developed in application was parameterized respectively. Due to the nature of rail traffic all the components of the model are described in a normal distribution.

The results of the simulation are shown in Figures 7-11. The limit of travel time was set to 25 minutes.
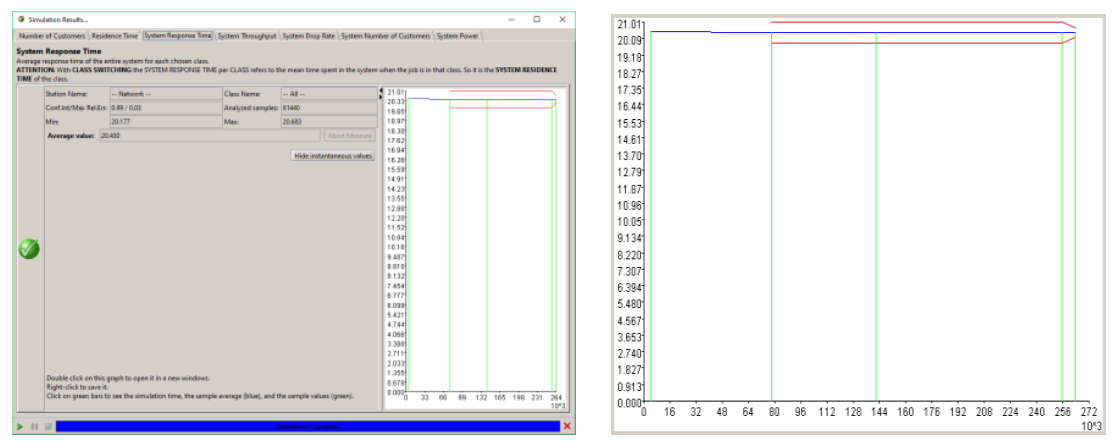

Fig. 7. Simulation results for option 0. 
Simulation models in testing reliability of transport process

Modele symulacyjne $w$ zastosowaniu do badania niezawodności procesów...
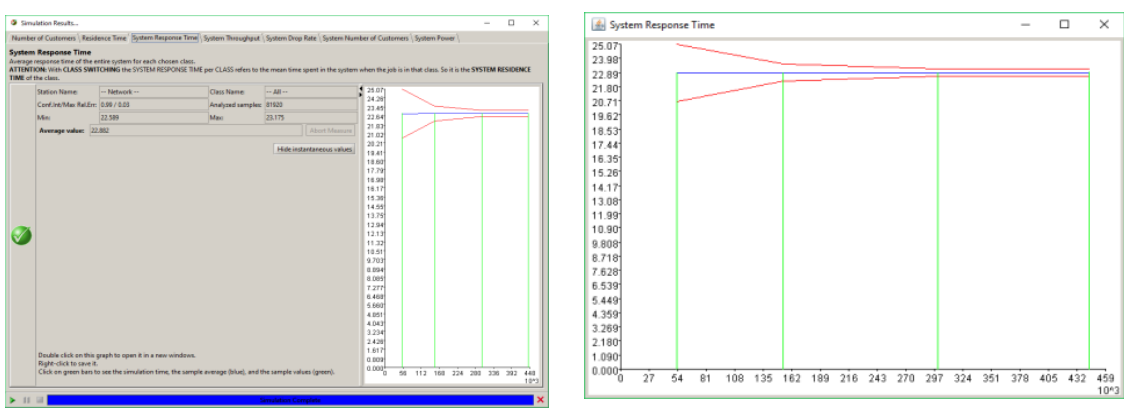

Fig. 8. Simulation results for option 1
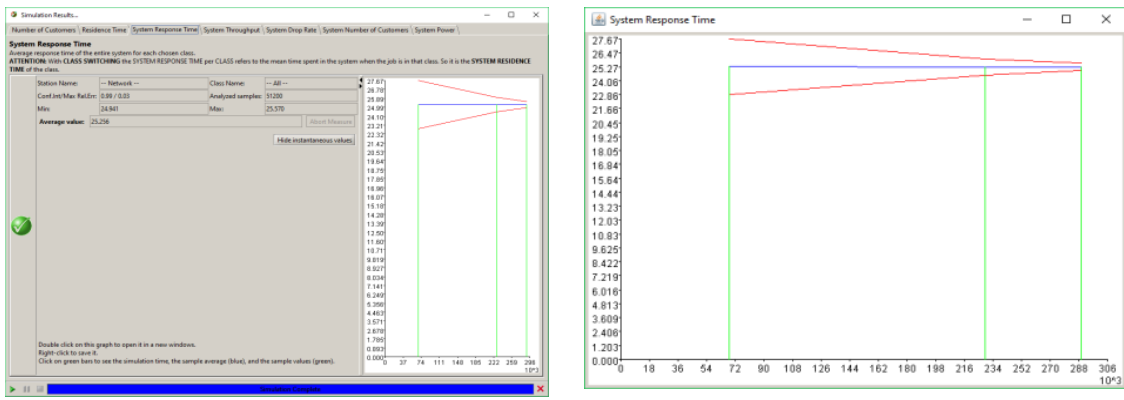

Fig.9. Simulation results for option 2
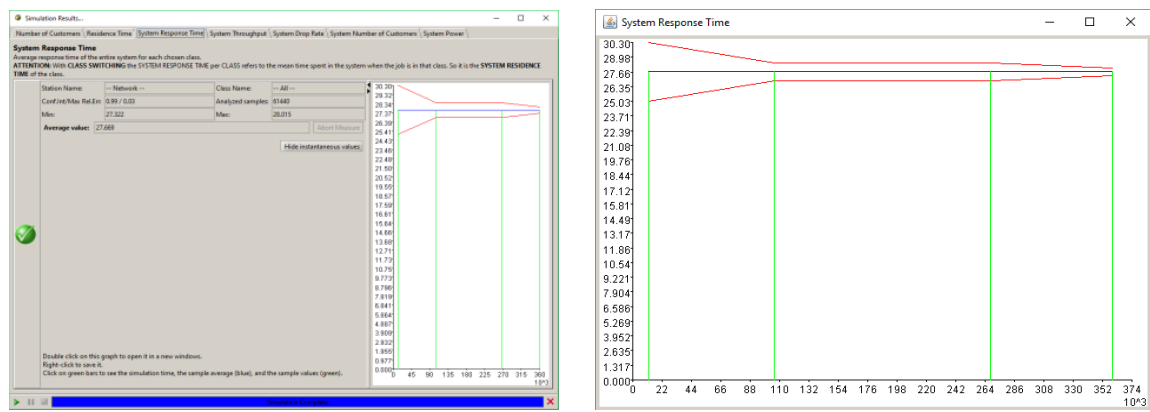

Fig. 10. Simulation results for option 3
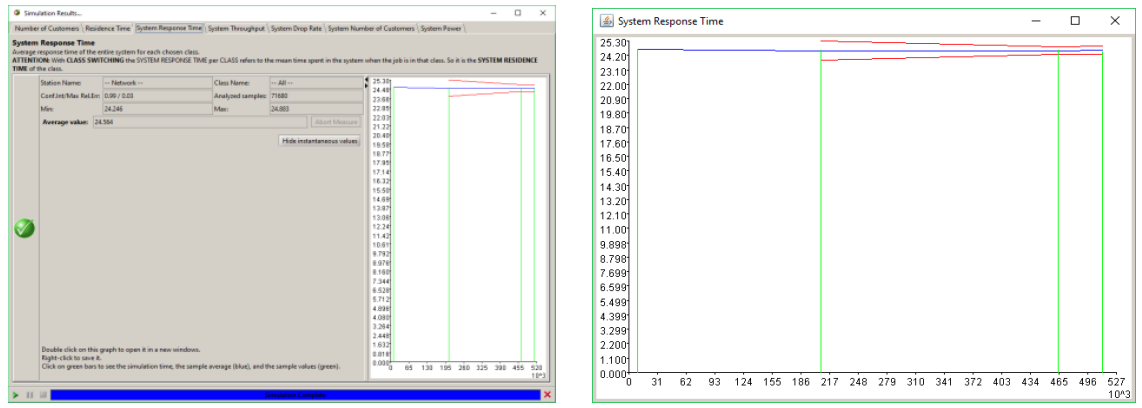

Fig. 11. Simulation results for option 4 
On the base of gained results about the loss of time one can notice that the condition is met for options $0-1$ and 4 . Therefore it can be concluded that in case of failure of more than one interval the phone announcement must be used.

\section{Conclusions}

Simulation tests are a good alternative for the study of transport processes. The solutions can be obtained by performing simulations on the models of processes. If it is possible processes can be improved and adapted to the requirements. The simulation is often the only possibility of getting answers to questions about implemented solutions.

The special area of application of simulation is studying real transport processes charged with loss of time. Processes of this kind occur on the railways when difficulties appear. The railway traffic organization prepared by the infrastructure manager assumes that the conditions are perfect - all processes are executed in accordance with the previously prepared plan. But the reality brings different situations that can cause interference like equipment failure. The simulation models can determine the time loss occurring in the process.

The article touches especially the reliability of traffic flow and transport process on railway lines in terms of failure of automatic block line. The zero-option shows the existing situation - when all devices are in working order and there are no traffic problems. In the following scenarios the automatic block lines on the route West Warsaw - Warsaw Wlochy are damaged or the phone announcing is introduced. Failures contributed to the time losses and thus the reliability of the process.

\section{Literature}

[1] Ambroziak T., Jacyna M.: Queueing theory approach to transport processes dynamics. Part I. Dynamics of transport network connections, Archives of Transport, vol. 14, iss 4, ITE, Warsaw 2002

[2] Bukowski L., Bezpieczeństwo i niezawodność systemów logistycznych, Materiały konferencyjne: VI Konferencja Logistyki Stosowanej TLM. Prace Wydziału Zarządzania Politechniki Częstochowskiej - Seminaria i Konferencje, SK 7, Zakopane 2002.

[3] Gołda P., Manerowski J. Support of aircraft taxiing operations on the apron, Journal of KONES Powertrain and Transport, Institute of Aviation (Aeronautics) BK, Vol. 21, No. 4, Warsaw 2014, str. 127-135

[4] Jacyna M., Lewczuk K., Kłodawski M., Technical and organizational conditions of designing warehouses with different functional structures. Journal of KONES Powertrain and Transport, Institute of Aviation (Aeronautics) BK, Vol. 22, No. 3, Warsaw 2015, str. 49-58,

[5] Jacyna M., Modelowanie i ocena systemów transportowych, Oficyna Wydawnicza Politechniki Warszawskiej, Warsaw 2009.

[6] Jacyna-Gołda I., Badanie niezawodności i efektywności funkcjonowania łańcuchów dostaw. Logistyka 4/2014, pp. 1947 - 1954.

[7] Jacyna-Gołda I., Decision-making model for supporting supply chain efficiency evaluation, Archives of Transport, Polska Akademia Nauk Komitet Transportu, vol. 33, Iss. 1, ss. 17-31, 2015. 
Simulation models in testing reliability of transport process

Modele symulacyjne w zastosowaniu do badania niezawodności procesów...

[8] Jacyna-Gołda I., Żak J.: Using queue theory to analysis and evaluation of the logistics centre workload, w: Archives of Transport, Polska Akademia Nauk - Komitet Transportu, vol. 25, nr 1, ss. 117-135, 2013

[9] Kaczor G.: Modelowanie i ocena niezawodności systemu transportu intermodalnego, Czasopismo Logistyka,

[10] Leszczyński J.: Modelowanie systemów i procesów transportowych, OWPW, Warsaw 1994.

[11] Lewczuk K., Żak J., Kłodawski M., Model of dynamic allocation of resources to the tasks of warehousing process (Conference proceedings) III Carpathian Logistics Congress, pp. 542-548. Dec 9-11, 2013, Krakow, Poland. 2014. TANGER Ltd.

[12] Nowakowski T., Niezawodność systemów logistycznych. Roz.: 4. Koncepcje niezawodności systemu, 6. Modele niezawodności elementu logistycznego. Oficyna Wydawnicza Politechniki Wrocławskiej, Wroclaw 2011.

[13] Słownik terminologiczny elektryki. Niezawodność. Jakość usługi. PN-93/N50191.

[14] Wasiak M.: Modelowanie przepływu ładunków w zastosowaniu do wyznaczania potencjału systemów logistycznych. Prace Naukowe Politechniki Warszawskiej, Transport, z.79, Oficyna Wydawnicza Politechniki Warszawskiej, Warsaw 2011.

[15] Żak J.: Modelowanie procesów transportowych metodą sieci faz. Oficyna Wydawnicza Politechniki Warszawskiej, Warszawa 2013

[16] Zarządzanie niezawodnością. Przewodnik zastosowań. Analiza ryzyka w systemach technicznych. PN-IEC 60300-3-9:1.

The work was realized as a part of statutory work of Warsaw University of Technology.

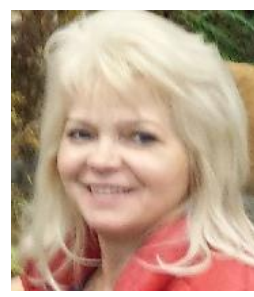

Professor Marianna Jacyna - researcher and teacher (professor) at the Warsaw University of Technology, Faculty of Transport, Department of Logistics and Transport Systems.

Areas of interest: optimization of transport and logistics processes, modelling, designing logistics facilities, multi-criteria evaluation. (Share: $50 \%$ ).

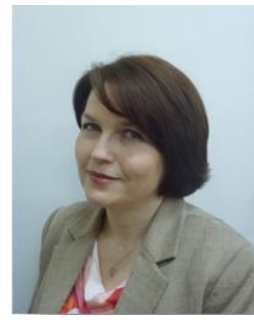

Jolanta Żak, Ph.D. - researcher and teacher (assistant professor) at the Warsaw University of Technology, Faculty of Transport, Department of Logistics and Transport Systems. Areas of interest: optimization and modelling of logistics and transport processes. (Share: 50\%). 


\section{MODELE SYMULACYJNE W ZASTOSOWANIU DO BADANIA NIEZAWODNOŚCI PROCESÓW TRANSPORTOWYCH}

\section{Wstęp}

Zagadnienia dotyczące transportu stanowią przedmiot badań wielu naukowców. Wynika to między innymi ze stale aktualnego dążenia, w szczególności przez rządy wielu państw, do wykorzystywania do przemieszczania ładunków i osób takich form które zapewniają:

- zmniejszenie kongestii,

- oszczędności energii,

- brak negatywnego wpływu na środowisko naturalne,

- wysoką efektywność.

Podstawowym celem badań systemów transportowych jest określenie zależności między zadaniami systemu, jego wyposażeniem oraz organizacją. Jak wiadomo każdy system, również transportowy, zmienia się w czasie zatem należy w nim uwzględnić właściwości pozwalające na odwzorowanie przebiegu tych zmian. Realizacja procesów transportowych przemieszczania osób lub ładunków wymaga odwzorowania [4]: sieci transportowej, wykorzystywanego do przewozu taboru, wszelkiego typu stacji obsługi ruchu towarowego i osobowego oraz przystanków osobowych, urządzeń zabezpieczenia a także pracowników stanowiących tzw. „załogę systemu”.

W różnych etapach procesu transportowego wymagane jest podejmowanie decyzji dotyczących sterowania realizacją procesu [1]. Podejmowane decyzje wpływają na przebieg realizacji procesu spełniając warunki brzegowe wynikające z ograniczeń wyposażenia sieci oraz oczekiwań odbiorcy usług. Ponieważ w realizacji procesu transportowego uczestniczą różne podmioty istotne jest aby organizacja procesu zapewniała niezawodność realizacji zadań zgłoszonych przez nabywców usług transportowych [1].

Uwzględniając powyższe wśród kryteriów stosowanych podczas oceny procesów transportowych nie może zabraknąć niezawodności działania procesu oraz efektywności realizacji zadań transportowych.

W przypadku oceny procesów transportowych analiza ich przebiegu może być dokonana poprzez badania symulacyjne wykonywane na modelach tych systemów [1]. Badania, te pozwalają zaobserwować wpływ na wydajność systemów przyjętego w nich wyposażenia oraz stosowanej organizacji pracy oraz na wstępną ocenę niezawodności związaną z jej funkcjonowaniem.

\section{Obszary realizacji procesów transportowe}

W artykule przyjęto, że proces transportowy to ciąg kolejnych zmian stanów systemu transportowego występujących między stanem początkowym a stanem końcowym. 
Simulation models in testing reliability of transport process

Modele symulacyjne w zastosowaniu do badania niezawodności procesów...

Przy czym jako stan systemu transportowego w wyróżnionej chwili przyjęto stan elementów dróg (elementów sieci drogowej, kolejowej - elementy liniowe i punktowe wraz z urządzeniami zabezpieczenia ruchu, itp.) oraz stan pojazdów lub stan potoku ruchu w wyróżnionej chwili. Zatem składowymi stanu systemu transportowego są stany pojedynczych elementów dróg oraz stany pojedynczych pojazdów.

Ponieważ system transportowy zawiera elementy biorące udział $\mathrm{w}$ procesie przemieszczania osób lub ładunków i elementy związane $\mathrm{z}$ procesem przemieszczania [15], [4] to dla procesów transportowych charakterystyczne są związki między stanami elementów dróg i stanami pojazdów. Przy czym stany elementów dróg wyznaczają jednoznacznie stany pojazdów i odwrotnie.

Przeprowadzanie przez system jednostek potoku ruchu związane jest $\mathrm{z}$ transformacją jednostek wejściowych $\mathrm{w}$ jednostki wyjściowe. Transformacje strumieni wejściowych $\mathrm{w}$ wyjściowe przedstawiono na rys.1

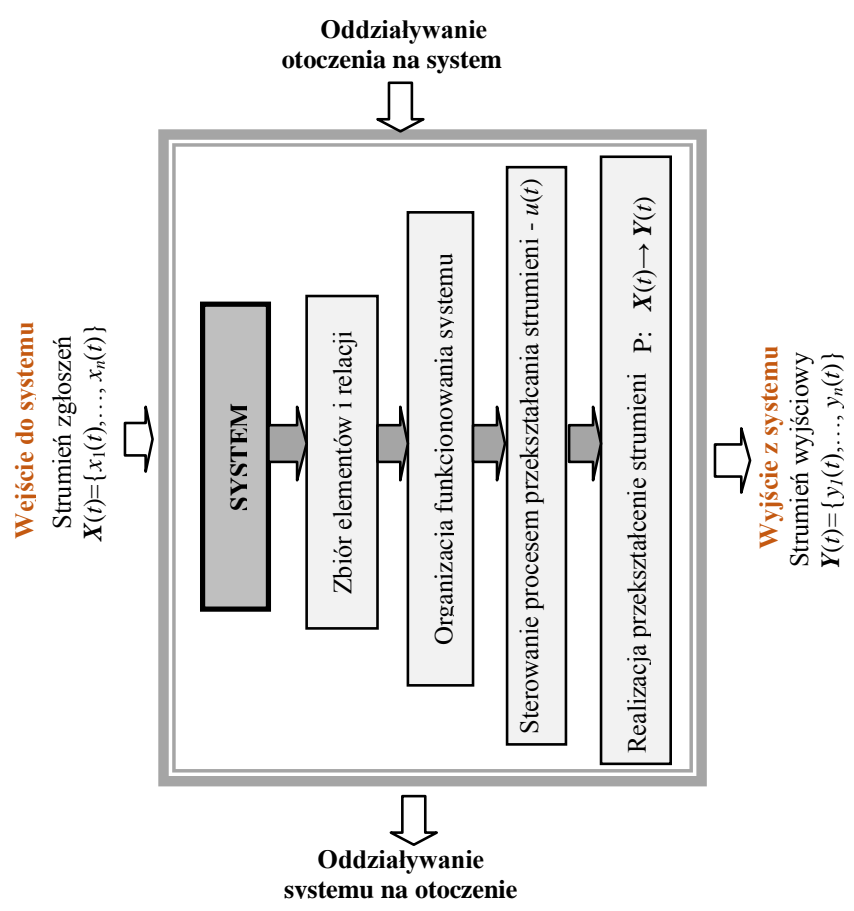

Rys. 1. Transformacja strumieni transportowych wejściowych w wyjściowe Źródto:[15].

Odwzorowanie procesu transportowego w modelu wymaga przyjęcia wielu założeń dotyczących określenia: relacji przemieszczania, rodzaju, liczby oraz cech przemieszczanych obiektów w systemie transportowym. Jednocześnie zmienna intensywność strumieni jednostek ruchu, powoduje, że procesy transportowe mogą mieć charakter stacjonarny lub (częściej) niestacjonarny który utrudnia prowadzenie badań. 
$\mathrm{Na}$ podstawie przeprowadzonej analizy literatury należy stwierdzić, że problematyka procesów transportowych obejmuje swoim zakresem następujące obszary:

1) Przemieszczanie potoku ruchu po elementach infrastruktury transportowej, obejmujące:

- odwzorowanie prędkości i przepustowości dróg w funkcji natężenia ruchu,

- odwzorowanie powstawania i wielkości kolejek w elementach infrastruktury,

- odwzorowanie kongestii ruchu, w tym sterowanie kongestią.

2) Sterowania sygnalizacją świetlną.

3) Obsługę pasażerów i ładunków w tym m.in.:

- optymalizację czasów wyjazdu pojazdów, wielkości przewozów,

- szacowanie zapasów magazynowych w funkcji ciągłości produkcji i dystrybucji,

- harmonogramowanie przemieszczania pojazdów na trasach $\mathrm{z}$ wieloma punktami zatrzymania, badanie separacji czasowej między kursami i jej wpływu na decyzje klientów, w tym układanie i badanie rozkładów jazdy,

- planowanie produkcji i dystrybucji, np. podejmowania decyzji w zakresie typów pojazdów, częstotliwości kursowania, itp.

4) Procesy występujące $w$ transporcie lotniczym oraz pracę portów lotniczych obejmujące:

- kolejkowanie operacji startu i lądowania;

- operacje startu i lądowania [3];

- proces obsługi (wydawania) bagażu w terminalach lotniczych.

5) Procesy występujące $w$ transporcie kolejowym obejmujące m.in.:

- analizę wydajności stacji węzłowych w funkcji przepływu wagonów próżnych, przejazdu pociągów i zdolności obsługowych,

- proces rozrządzania na stacjach rozrządowych,

- kolejność przejazdu pociągów (wykorzystanie mijanek, stacji itd.) na linii,

- sterowanie ruchem z uwzględnieniem prędkości, priorytetów, stanu technicznego infrastruktury i rozkładów jazdy.

6) Procesy magazynowe obejmujące m.in.:

- wyznaczanie pojemności obszarów funkcjonalnych czy buforowych,

- analizę układów transportowych na wejściu i wyjściu do magazynów,

- kolejkowanie przyjęć i odbioru ładunków.

$\mathrm{W}$ każdym $\mathrm{z}$ wymienionych zagadnień, prowadzenie badań $\mathrm{W}$ zakresie realizowanych procesów wymaga budowy odpowiedniego modelu, pozwalającego na analizę przebiegu zachodzących zjawisk w systemie transportowym.

$\mathrm{W}$ artykule analizowany będzie proces transportowy występujący $\mathrm{w}$ obszarze transportu kolejowego. 
Simulation models in testing reliability of transport process

Modele symulacyjne w zastosowaniu do badania niezawodności procesów...

\section{Metoda sieci faz w zastosowaniu do badania niezawodności procesu transportowego}

Według definicji niezawodność jest to zdolność obiektu do spełnienia stawianych mu wymagań, której miernikiem może być prawdopodobieństwo spełniania tych wymagań. Oczywiście podczas oceny niezależności należy uwzględnić czas działania obiektu (systemu) w którym analizowany obiekt (system) jest zdatny do prawidłowego użytkowania (sprawny). Miarą oceny w takim przypadku może być czas, ilość wykonanej pracy, liczba wykonanych czynności, długość przebytej drogi itp.

W ujęciu technicznym, zgodnie z normą PN-93/N-50191[13] niezawodność systemu (obiektu technicznego) jest definiowana jako zespół właściwości, które opisują gotowość obiektu i wpływające na nią: nieuszkadzalność, obsługiwalność i zapewnienie środków obsługi. Inna definicja wyróżnia dwa rodzaje niezawodności: probabilistyczne i deterministyczne w zależności od uwzględnienia (lub nie) losowości charakterystyk danych obiektu (systemu).

W przypadku modeli probabilistycznych niezawodność obiektu $\boldsymbol{R}$, opisana jest wzorem

$$
R(t)=P(T \geq t)
$$

gdzie:

$R(t) \quad$ - niezawodność obiektu $\mathrm{R}$ w danej chwili $t$

$P(T \geq t)$ - prawdopodobieństwo, że obiekt będzie sprawny (trwałość), dłużej niż wynosi t. Trwałość $T$ może być wyrażona np. czasem, długością w [km].

Wielu naukowców zajmowało się problematyką niezawodności w obszarze logistyki. I. Jacyna-Gołda w pracy [6] zajmowała się badaniem niezawodności łańcuchów dostaw. Natomiast niezawodność systemów logistycznych została omówiona w pracach T. Nowakowskiego [12] i L. Bukowski [2].

Podczas oceny niezawodności funkcjonowania procesu transportowego najważniejszym miernikiem jest czas. $\mathrm{W}$ pewnych sytuacjach zarówno przyjazd przed czasem jak i spóźnienie stanowią o niewykonaniu zadania przewozowego. Miara niezawodności procesu jest wówczas sformułowana jako:

$$
R(t)=P\left(t-t_{w} \leq T \leq t+t_{s}\right)
$$

gdzie:

$t-t_{w}-$ najwcześniejszy dopuszczalny czas przyjazdu.

$t+t_{s}-$ najpóźniejszy dopuszczalny czas przyjazdu

Realizację każdego zadania w systemie transportowym można podzielić na kilka etapów. Modelowanie takich systemów i ocena ich niezawodności w oparciu o klasyczne techniki teorii niezawodności nie zawsze przynoszą oczekiwane rezultaty. W takim przypadku proponowane są inne metody obliczeniowe, np. modele wykorzystujące procesy Markowa lub niezawodnościowe diagramy (struktury) fazowe[9]. Jedną z metod wykorzystującą procesy Markowa jest metoda sieci faz procesu przedstawiona w pozycji [15]. 
Dla procesu transportowego charakterystyczne są związki między stanami elementów dróg i stanami pojazdów. Przy czym, stany elementów dróg wyznaczają jednoznacznie stany pojazdów i odwrotnie. Zależności te znacznie ograniczają liczbę dopuszczalnych stanów systemu transportowego. Pozwala to na przedstawienie wektora stanu systemu transportowego jako ciągu zmian stanu elementów infrastruktury systemu, lub jako ciągu zmian stanu pojazdów w systemie, np. samochodów, pociągów. W metodzie sieci faz procesu przyjmuje się, że stan systemu będzie stanowić fazę procesu, a zmianę stanu (przejście $\mathrm{z}$ danej fazy procesu do następnej) określa się jako zdarzenie.

Powstała $\mathrm{w}$ ten sposób strukturę definiowana jest jako struktura sieci faz procesu przemieszczania. Założono, że względem czasu fazę procesu charakteryzuje czas jej trwania, zaś zdarzenie chwila jego wystąpienia. W takim układzie struktura sieci faz procesu przemieszczania jest odwzorowaniem struktury transportowej oraz odwzorowaniem procesu przemieszczania jednostek transportowych w sieci transportowej.

Przykład przejścia ze struktury sieci transportowej na strukturę sieci faz procesu przedstawiono na rys 2 .

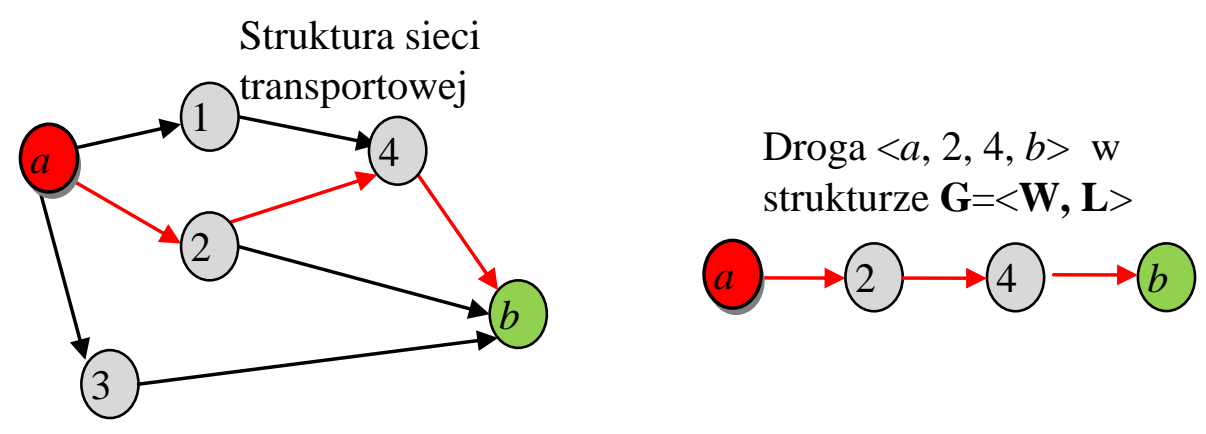

Struktura sieci faz procesu dla drogi $\langle a, 2,4, b\rangle$

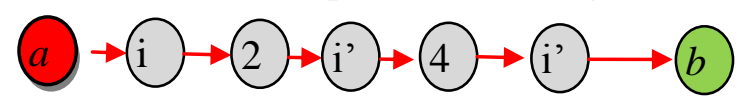

Rys. 2. Przykład zamiany struktury sieci transportowej w strukture sieci faz Źródto:[15].

Każda faza przedstawiana jest jako prosty system masowej obsługi (SMO). Oznacza to, że dla każdej fazy wyróżniony jest strumień zgłoszeń jednostek transportowych (pojazdów) do kolejnej fazy obsługi, poczekalnię jako miejsce oczekiwania pojazdów na obsługę, stanowiska obsługi w tej fazie obsługi oraz strumień obsłużonych pojazdów.

Przy tak przyjętych założeniach, sieć faz procesu odwzorowuje zależności między fazami procesu, a struktura sieci faz procesu odwzorowuje strukturę procesu transportowego, przy czym każda $\mathrm{z}$ faz stanowi węzeł struktury a zdarzenie jej łuk. 
Simulation models in testing reliability of transport process

Modele symulacyjne w zastosowaniu do badania niezawodności procesów...

Zatem węzeł sieci faz, w zależności od sytuacji, może odwzorowywać element drogi zarówno punktowy (węzeł) jak i liniowy (połączenie transportowe).

Uwzględniając powyższe model procesów transportowych (MPTSF) będzie zapisany, jako uporządkowana czwórka, postaci:

$$
\mathrm{MPTSF}=<\text { GFSP }, \text { FFSP }, \text { ZST }, \text { SFP }>
$$

gdzie:

GFSP - struktura sieci faz procesu,

FFSP - zbiór funkcji określonych na elementach struktury sieci faz

ZST - wielkość strumienia zgłoszeń

SFP - sterowanie w postaci organizacji ruchu.

Każda faz ma ściśle określony czas trwania. W związku z tym, struktura niezawodności systemu zmienia się $\mathrm{w}$ zależności od aktualnie wykonywanych zadań. Aby realizacja celu - przyjazdu do punktu końcowego została osiągnięta, każde z zadań musi zostać wykonane a ewentualne straty czasy, będące miarą niezawodności, nie mogą przekraczać założonych ograniczeń. W przypadku gdy czas pobytu pojazdu w systemie jest wyższy niż zakładany, przyjmuje się, że główny cel, którym było dotarcie w przyjętym czasie do punktu końcowego, został niewykonany.

\section{Modele symulacyjne procesów transportowych}

Jak wspomniano we wstępie w przypadku rozważań dotyczących przebiegu procesu transportowego, niezbędnym jest zbudowanie modeli procesów umożliwiających prowadzenie badań symulacyjnych. W takim przypadku należy odpowiednio odwzorować wszystkie istotne z punktu widzenia prowadzonych badań cechy przebiegu procesu. Badając proces przy pomocy zbudowanego modelu procesu poszukujemy odpowiedzi na pytania dotyczące m.in. poziomu niezawodność realizacji zadań zgłoszonych przez nabywców usług transportowych.

Modele symulacyjne umożliwiają naśladowanie procesu zachodzącego w systemie, co prowadzi do uzyskania informacji, które można przenieść w obszar rzeczywistości. Zatem model taki jest użyteczny, gdy trzeba określić skutki różnych decyzji, zarówno podczas projektowania lub analizy istniejących rozwiązań. W literaturze można znaleźć wiele przykładów zastosowania technik symulacyjnych do opisu zagadnień transportowych. Na przykład J. Leszczyński przedstawił sformalizowany opis zdarzeniowego modelu symulacyjnego stacji rozrządowej. Metodę badania dynamiki procesów transportowych zaproponowali T. Ambroziak i M. Jacyna [1]. Przedstawione przez nich podejścia oparte są na teorii masowej obsługi oraz teorii programowania dynamicznego. Model symulacyjny procesów logistycznych oparty na czasowym generatorze zdarzeń opracował M. Wasiak [14].

Modele symulacyjne umożliwiają prowadzenie eksperymentów na rzeczywistych systemach i procesach transportowych oraz prowadzenia badań w zakresie wpływu na ich zachowanie parametrów związanych z tymi systemami lub procesami. 
Tym samym w procesie budowy modelu symulacyjnego dla konkretnego systemu transportowego należy szczególną uwagę zwrócić na etap identyfikacji parametrów modelu. Ponieważ między innymi od poprawności realizacji tego etapu w sposób bezpośredni zależy poprawność całego modelu oraz wnioskowania na jego podstawie. Weryfikacja założeń dotyczących rozkładów prawdopodobieństwa zmiennych losowych, które występują w modelu symulacyjnym może być realizowana np. za pomocą testu Kołmogorowa. W praktyce można zauważyć, że dąży się do dokładnego planowania działań realizowanych $\mathrm{w}$ systemach transportowych, jednak w ujęciu ogólnym ze względu na zakres tych działań np. czasy obsługi są różne. Stąd też można je opisać rozkładami prawdopodobieństwa. Diagram zależności między systemem rzeczywistym i modelem symulacyjnym przedstawiono na rys. 3 .

Ważnym elementem procesu modelowania jest ocena na ile model odpowiada systemowi rzeczywistemu i $\mathrm{w}$ jakim stopniu prawdziwe są wyniki symulacji wykonanej na tym modelu. W obu przypadkach ocena modelu jest przeprowadzana na podstawie rezultatów działania systemu, a nie na podstawie kontroli wewnętrznych mechanizmów generujących te wyniki.

Podczas oceny jakościowej zbiera się i bada chwilowe wyniki obliczeń programu symulacyjnego. Ocena ilościowa, czyli ocena wiarygodności rezultatów symulacji wykonanej przy pomocy danego modelu sprowadza się do porównania tych rezultatów z obserwacjami systemu rzeczywistego przy pomocy statystycznych testów zgodności. Polega to na wykorzystania analizy statystycznej, w której uwzględnia się analizę wariancji (lub nieparametryczne testy zgodności).

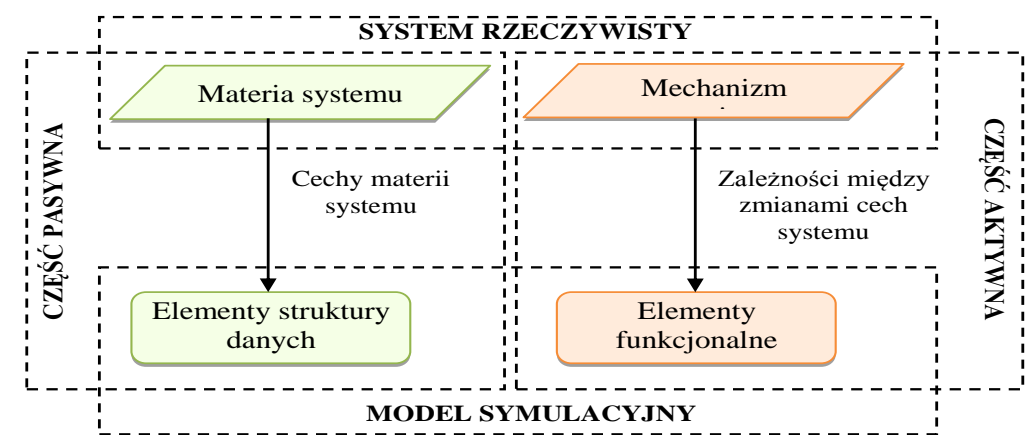

Rys. 3. Zależności między systemem rzeczywistym i modelem symulacyjnym. [15]

\section{Kryterium oceny procesów transportowych $w$ aspekcie niezawodności}

$\mathrm{Z}$ punktu widzenia niezawodności procesu transportowego jednym z ważniejszych kryteriów oceny realizacji procesu transportowego są ważone straty czasu pojazdów. Straty te powstają na skutek sytuacji konfliktowych występujących podczas transportu. Rozwiązywanie konfliktów polega na bieżącym oddziaływaniem na potok ruchu $\mathrm{w}$ sposób zmierzający do poprawy jakości realizacji procesu transportowego, odniesionej do przyjętego kryterium oceny. 
Simulation models in testing reliability of transport process

Modele symulacyjne w zastosowaniu do badania niezawodności procesów...

Żeby oddziaływanie takie miało sens musi istnieć pewna swoboda działania w ramach ograniczeń narzuconych przez organizację ruchu oraz wyposażenie systemu.

Wartość kryterium sumy ważonych strat czasu pojazdów wyznaczana jest w oparciu o symulację kolejnych decyzji dotyczących przemieszczania pojazdów do kolejnej fazy procesu. A następnie do realizacji wybierana jest decyzja najkorzystniejsza pozwalająca na uniknięcie największych strat. Dopuszcza się pozostawienie jednostki $\mathrm{w}$ tej samej fazie jeżeli pozwala to uniknąc większych strat innych jednostek znajdujących się w obszarze analizy. Obszar analizy łączy przestrzeń określoną przez liczbą węzłów sieci z czasem trwania faz procesu, a dokładnie $\mathrm{z}$ czasem oczekiwań jednostek i czasem trwania obsług w węzłach sieci faz procesu. Wygodnie jest operować $w$ takich przypadkach pojęciem przedziału czasu $\mathrm{h}$ odniesionym do v-tego węzła sieci faz procesu i $s t$-tego pojazdu znajdującego się w obszarze analizy. Dla uniknięcia wpływu skończonego czasu symulacji przyjmujemy założenie, że dla każdej jednostki potoku ruchu i fazy procesu analizowany przedział czasu jest dużo mniejszy od czasu badania. Stratę czasu w przedziale czasu $h$, wynikającą z pozostawienia $s t-$ tego pojazdu $\mathrm{w} v$-tej fazie procesu, liczoną względem chwili podejmowania decyzji $t_{0}$ oznaczono przez $w(v, s t, t)$. Wartość funkcji strat czasu dla pojedynczego pojazdu oznaczono symbolem $\Delta T(v, s t)$ oraz wyrażono następująco:

$$
\forall v \in \boldsymbol{V}, \quad \forall s t \in \boldsymbol{S T} \quad \Delta T(v, s t)=\int_{t_{0}}^{t_{0}+h} \omega(v, s t, t) d t
$$

Wartość funkcji strat czasu w analizowanym przedziale dla wszystkich pojazdów oznaczono symbolem $\Delta T(v)$ oraz wyrażono następująco:

$$
\forall v \in \boldsymbol{V} \quad \Delta T(v)=\sum_{s t \in S T} \int_{t_{0}}^{t_{0}+h} \omega(v, s t, t) d t
$$

Wartość funkcji całkowitych strat czasu oznaczono symbolem $\Delta T$ oraz wyrażono następująco:

$$
\Delta T=\sum_{v \in V} \sum_{s t \in S T} \int_{t_{0}}^{t_{0}^{+h}} \omega(v, s t, t) d t
$$

Ocena niezawodności funkcjonowania procesu transportowego ze względu na funkcji całkowitych strat czasu. Miara niezawodności procesu jest wówczas sformułowana jako:

$$
R(t)=P\left(\Delta T \leq t_{g}\right)=P\left(\sum_{v \in V} \sum_{s t \in S T} \int_{t_{0}}^{t_{0}+h} \omega(v, s t, t) d t \leq t_{g}\right)
$$

gdzie: $t_{g}$ - maksymalna wielkość strat . 


\section{Niezawodność procesu ruch pociągów na linii kolejowej}

Omówioną we wczesniejszych punktach metodę badania niezawodności zastosowano do oceny ruchu pociągów na liniach kolejowych. W artykule przeprowadzono badania niezawodnosci ruchu na dwóch szlakach:

1) szlak Warszawa Zachodnia - Warszawa Włochy - odcinek linii 447 Warszawa Zachodnia - Grodzisk Mazowiecki,

2) szlak Warszawa Włochy - Pruszków - odcinek linii 447 Warszawa Zachodnia - Grodzisk Mazowiecki,

dla kierunku zasadniczego - tory dedykowane dla ruchu pasażerskiego podmiejskiego. Schemat analizowanych odcinków przedstawiono na rys. 4.

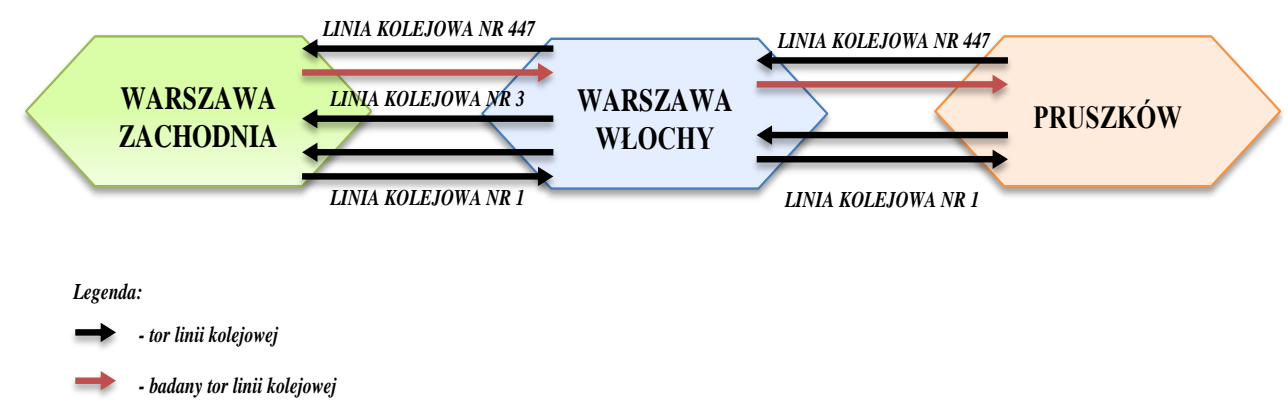

Rys. 4. Schemat analizowanych odcinków szlakowych

Charakterystykę analizowanych szlaków przedstawiono w tabeli 1. Wszystkie analizowane szlaki wyposażone są $\mathrm{w}$ liniowe urządzenia sterowania ruchem kolejowym w postaci samoczynnej blokady liniowej. W związku z tym szlak podzielony jest na kilka odstępów. Na każdym odstępie można znajdować się jeden pociąg. Elementami które wpływają na niezawodność procesu transportowego (najczęściej ulegającymi awarii) są urządzenia samoczynnej blokady liniowej. W zależności od liczby odstępów które uległy awarii pociąg musi przejechać je ze zmniejszoną do $20 \mathrm{~km} / \mathrm{h}$ prędkością lub wprowadza się telefoniczne zapowiadanie pociągów i rozkazem szczególnym „S” unieważnia się wskazania semaforów odstępowych. Na szlaku ponownie może znajdować się tylko jeden pociąg. W obydwu przypadkach wydłuża się czas jazdy a tym samym rosną straty czasu. W przypadku gdy straty te będą większe niż przyjęte można stwierdzić, że proces nie spełnia warunku niezawodności

Elementami modelu są: źródło pociągów, odstępy samoczynnej blokady liniowej, poszczególne stacje i posterunki oraz wyjście strumieni pociągów z systemu.

Analizowano straty czasu wynikające $\mathrm{z}$ różnych kombinacji awarii odstępów samoczynnej blokady liniowej na szlaku Warszawa Zachodnia-Warszawa Włochy. W badania przyjęto, że zdarzenia polegające na awarii poszczególnych semaforów są niezależne i na wielkość strat czasu nie wpływa miejsce awarii a ich liczba. 
Simulation models in testing reliability of transport process

Modele symulacyjne w zastosowaniu do badania niezawodności procesów...

Tabela 1. Charakterystyka analizowanych szlaków

\begin{tabular}{|l|c|c|}
\hline Parametr & $\begin{array}{c}\text { Szlak Wwa Zachodnia - } \\
\text { Wwa Włochy }\end{array}$ & $\begin{array}{c}\text { Szlak Wwa Włochy } \\
\text { - Pruszków }\end{array}$ \\
\hline Długość szlaku [km] & 3,722 & $9,087 \mathrm{~km}$ \\
\hline $\begin{array}{l}\text { Sredni czas przejazdu } \\
\text { pociagu typowego dla } \\
\text { szlaku [min] }\end{array}$ & 6 & $11 \mathrm{~min}$ \\
\hline Liczba odstępów & 5 & 6 \\
\hline Srednia długość 1 odstępu [m] & 744 & 1515 \\
\hline $\begin{array}{l}\text { Średni czas przejazdu 1 1 } \\
\text { odstępu [min] }\end{array}$ & $\begin{array}{c}1,2(3,6 \text { gdy występuje awaria } \\
\text { na odstępie samoczynnej } \\
\text { blokady liniowej })\end{array}$ & 1,83 \\
\hline $\begin{array}{l}\text { Liczba torów na stacji } \\
\text { poczatkowej }\end{array}$ & 5 & 1 \\
\hline $\begin{array}{l}\text { Liczba tó́w na stacji } \\
\text { końcowej }\end{array}$ & 1 & 2 \\
\hline
\end{tabular}

Badania symulacyjne niezawodności procesu przemieszczania pociągów na analizowanej linii kolejowej zostało przeprowadzone $\mathrm{z}$ wykorzystaniem aplikacji Java Modelling Tools - JSIMgraph w pięciu etapach: najpierw wykonano badania dla wariantu 0 (sytuacja bazowa - istniejąca), a następnie dla wariantów 1-3, odpowiadających sytuacji istniejącej po wystąpieniu odpowiedniej liczby awarii urządzeń samoczynnej blokady liniowej na szlaku Warszawa Zachodnia Warszawa Włochy oraz wariant 4 odpowiadający sytuacji telefonicznego zapowiadanie pociągów na tym szlaku.

Na rysunkach 5 i 6 przedstawiono model linii kolejowej dla wariantów $0-3$ oraz wariantu 4 stosując aplikację Java Modelling Tools.

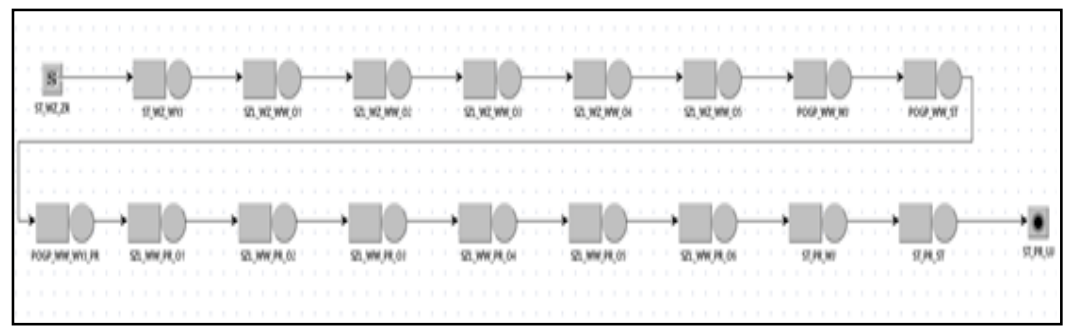

Rys. 5. Model linii kolejowej w postaci sieci faz procesów dla wariantów 0-3 w aplikacji Java Modelling Tools

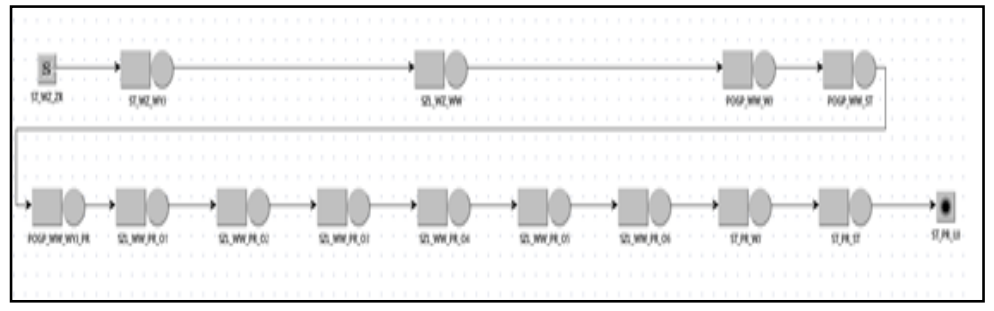

Rys. 6. Model linii kolejowej dla wariantu 4 w aplikacji Java Modelling Tools 
Wprowadzony do programu model został odpowiednio sparametryzowany. Ze względu na specyfikę ruchu kolejowego wszystkie elementy modelu zostały opisane rozkładem normalnym.

Wyniki przeprowadzonej symulacji przedstawiono na rys. 7-11. W badań przyjęto, że graniczny czas przejazdu wynosi 25 minut.
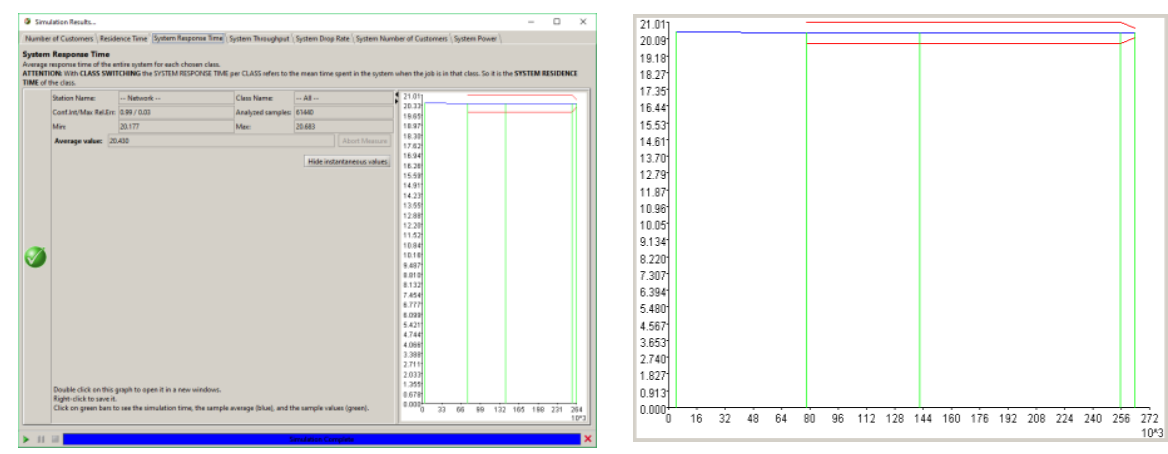

Rys. 7. Wyniki symulacji dla wariantu 0
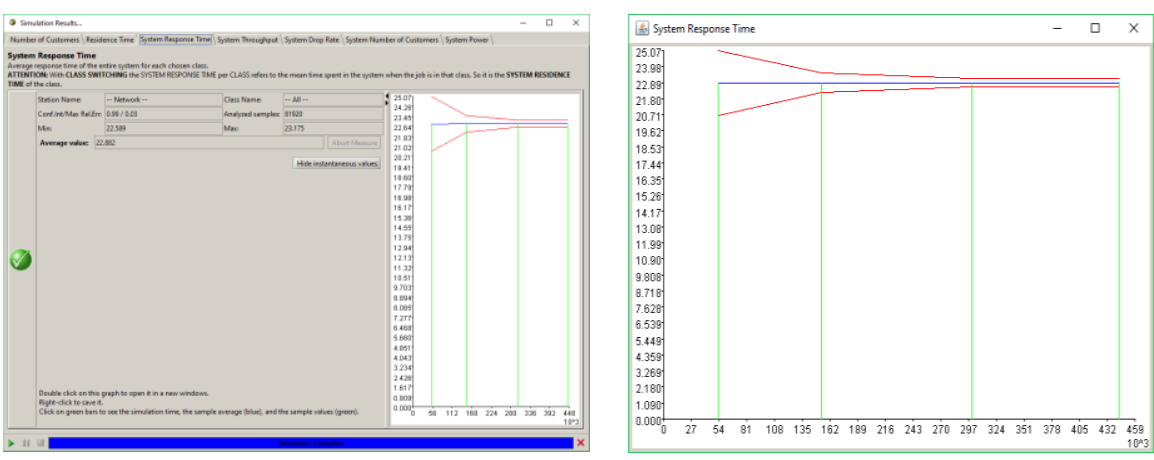

Rys. 8. Wyniki symulacji dla wariantu 1
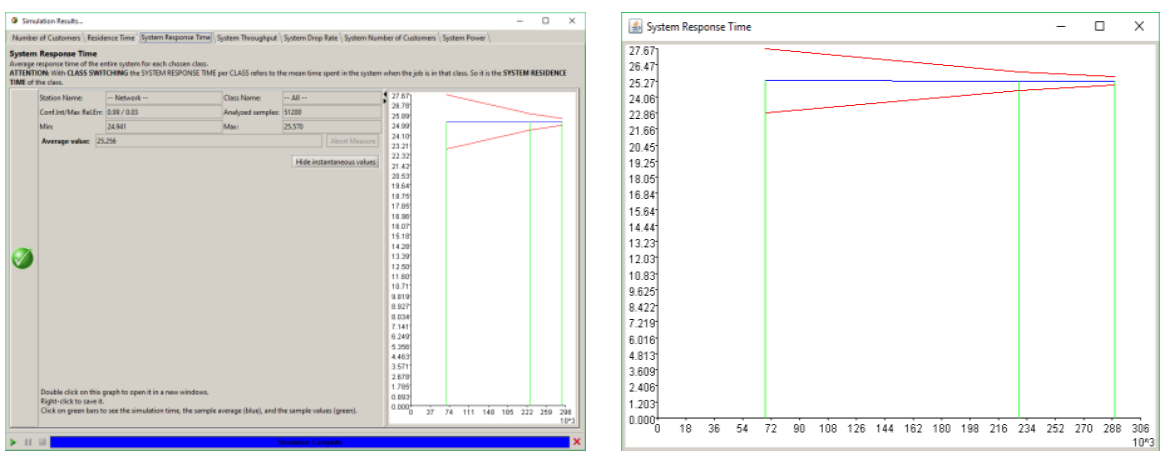

Rys.9. Wyniki symulacji dla wariantu 2 
Simulation models in testing reliability of transport process

Modele symulacyjne w zastosowaniu do badania niezawodności procesów...
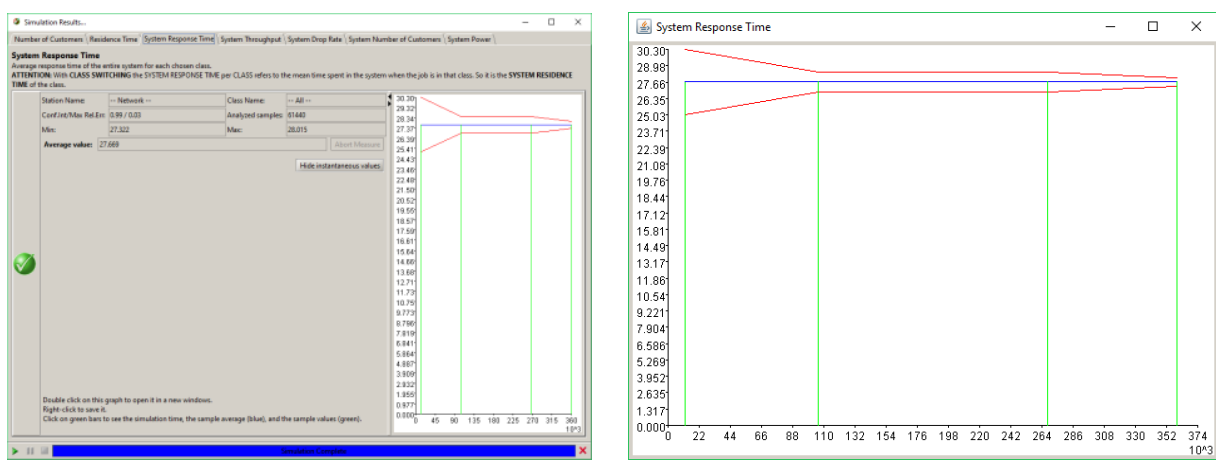

Rys. 10. Wyniki symulacji dla wariantu 3
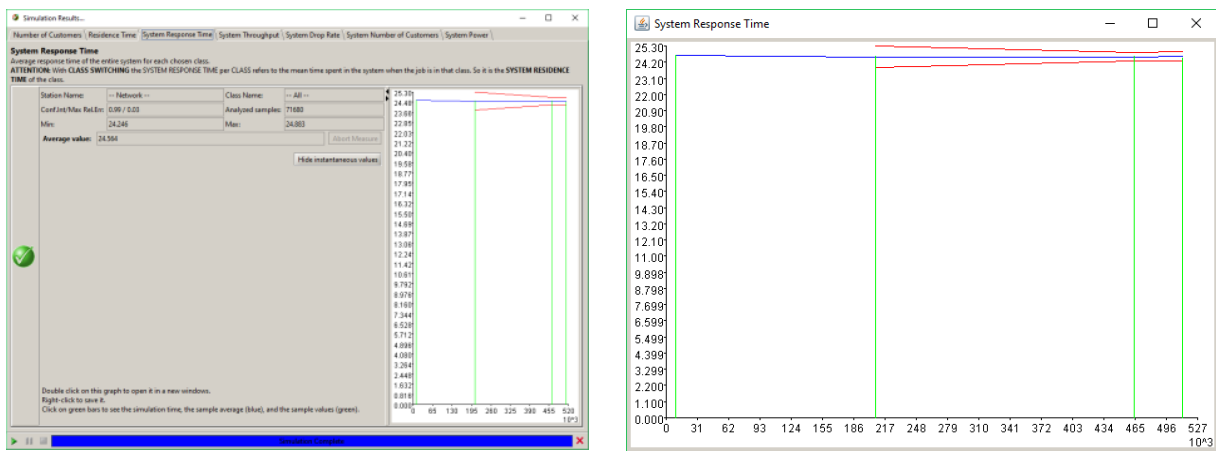

Rys. 11. Wyniki symulacji dla wariantu 4

$\mathrm{Na}$ podstawie analizy otrzymanych wyników dotyczących strat czasu można stwierdzić, że warunek ten jest spełniony dla wariantów 0-1 oraz wariantu 4. Można zatem stwierdzić, że w przypadku awarii więcej niż jednego odstępu należy stosować zapowiadanie telefoniczne.

\section{Podsumowanie}

Badania symulacyjne stanowią dobrą alternatywę dla badań procesów transportowych. Wyznaczone rozwiązania można uzyskać wykonując symulacje na modelach procesów oraz $\mathrm{w}$ miarę możliwości poprawiać i dostosowywać analizowane procesy do ustalonych wymogów. Często stanowią jedyną możliwością na uzyskanie odpowiedzi na pytania dotyczące wdrażanych rozwiązań.

Szczególnym obszarem zastosowania transportu jest badanie rzeczywistych procesów transportowych, w których występują straty czasu. Takie procesy występują w ruchu kolejowym w przypadku wystąpienia utrudnień. Organizacja ruchu kolejowego przygotowana przez zarządcę infrastruktury zakłada, że występuje stan idealny - wszystkie procesy realizowane są zgodnie z uprzednio przygotowanym planem. 
Jednak w życiu mogą wystąpić różne sytuacje, które mogą wywołać zakłócenia np. awaria urządzeń. Z wykorzystaniem modeli symulacyjnych można wyznaczyć straty czasu występujące w procesach.

W artykule przeprowadzono badania płynności ruchu na liniach kolejowych w zakresie wystąpienia awarii urządzeń samoczynnej blokady liniowej w aspekcie niezawodności procesu transportowego. W wariancie zerowym przedstawiono sytuację istniejącą - gdy wszystkie urządzenia są sprawne i nie występują utrudnienia $\mathrm{w}$ ruchu. W kolejnych wariantach przyjęto, że ulegną uszkodzeniu urządzenia samoczynnej blokady liniowej na szlaku Warszawa Zachodnia Warszawa Włochy lub zostanie wprowadzone zapowiadanie telefoniczne. Awarie wpłynęły na wielkość strat czasu a tym samym na niezawodność procesów.

\section{Literatura}

[1] Ambroziak T., Jacyna M.: Queueing theory approach to transport processes dynamics. Part I. Dynamics of transport network connections, Archives of Transport, vol. 14, iss 4, ITE, Warszawa 2002

[2] Bukowski L., Bezpieczeństwo i niezawodność systemów logistycznych, Materiały konferencyjne: VI Konferencja Logistyki Stosowanej TLM. Prace Wydziału Zarządzania Politechniki Częstochowskiej - Seminaria i Konferencje, SK 7, Zakopane 2002.

[3] Gołda P., Manerowski J. Support of aircraft taxiing operations on the apron, Journal of KONES Powertrain and Transport, Institute of Aviation (Aeronautics) BK, Vol. 21, No. 4, Warsaw 2014, str. 127-135

[4] Jacyna M., Lewczuk K., Kłodawski M., Technical and organizational conditions of designing warehouses with different functional structures. Journal of KONES Powertrain and Transport, Institute of Aviation (Aeronautics) BK, Vol. 22, No. 3, Warsaw 2015, str. 49-58,

[5] Jacyna M., Modelowanie i ocena systemów transportowych, Oficyna Wydawnicza Politechniki Warszawskiej, Warszawa 2009.

[6] Jacyna-Gołda I., Badanie niezawodności i efektywności funkcjonowania łańcuchów dostaw. Logistyka 4/2014, str. 1947 - 1954.

[7] Jacyna-Gołda I., Decision-making model for supporting supply chain efficiency evaluation, Archives of Transport, Polska Akademia Nauk Komitet Transportu, vol. 33, Iss. 1, ss. 17-31, 2015.

[8] Jacyna-Gołda I., Żak J.: Using queue theory to analysis and evaluation of the logistics centre workload, w: Archives of Transport, Polska Akademia Nauk Komitet Transportu, vol. 25, nr 1, ss. 117-135, 2013

[9] Kaczor G.: Modelowanie i ocena niezawodności systemu transportu intermodalnego, Czasopismo Logistyka,

[10] Leszczyński J.: Modelowanie systemów i procesów transportowych, OWPW, Warszawa 1994 
Simulation models in testing reliability of transport process

Modele symulacyjne w zastosowaniu do badania niezawodności procesów...

[11] Lewczuk K., Żak J., Kłodawski M., Model of dynamic allocation of resources to the tasks of warehousing process (Conference proceedings) III Carpathian Logistics Congress, pp. 542-548. Dec 9-11, 2013, Krakow, Poland. 2014. TANGER Ltd.

[12] Nowakowski T., Niezawodność systemów logistycznych. Roz.: 4. Koncepcje niezawodności systemu, 6. Modele niezawodności elementu logistycznego. Oficyna Wydawnicza Politechniki Wrocławskiej, Wrocław 2011.

[13] Słownik terminologiczny elektryki. Niezawodność. Jakość usługi. PN-93/N50191.

[14] Wasiak M.: Modelowanie przepływu ładunków w zastosowaniu do wyznaczania potencjału systemów logistycznych. Prace Naukowe Politechniki Warszawskiej, Transport, z.79, Oficyna Wydawnicza Politechniki Warszawskiej, Warszawa 2011.

[15] Żak J.: Modelowanie procesów transportowych metodą sieci faz. Oficyna Wydawnicza Politechniki Warszawskiej, Warszawa 2013

[16] Zarządzanie niezawodnością. Przewodnik zastosowań. Analiza ryzyka w systemach technicznych. PN-IEC 60300-3-9:1

Praca realizowana $w$ ramach pracy statutowej Politechniki Warszawskiej.

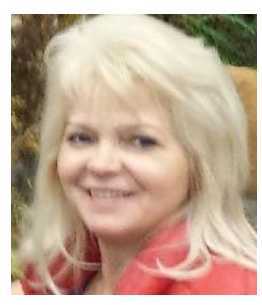

Marianna Jacyna, prof. zw. dr hab. inz. - pracownik naukowodydaktyczny (profesor) na Wydziale Transportu Politechniki Warszawskiej w Zaktadzie Logistyki i Systemów Transportowych. Obszary zainteresowania: optymalizacja procesów transportowych i logistycznych, modelowanie, projektowanie obiektów logistycznych, ocena wielokryterialna. (Udziat: 50\%).

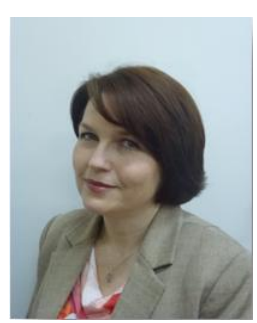

Jolanta Żak, dr hab. - pracownik naukowo-dydaktyczny (adiunkt) na Wydziale Transportu Politechniki Warszawskiej w Zakładzie Logistyki i Systemów Transportowych. Obszary zainteresowania: optymalizacja $i$ modelowanie procesów transportowych i logistycznych.(Udziat: 50\%). 